To cite this article: Dr Vijetha Jadda (2022). CONSUMERS' PERCEPTION TOWARDS BANK ADVERTISING AND ITS' IMPACT ON CONSUMER DECISION MAKING, International Journal of Research in Commerce and Management Studies (IJRCMS) 4 (1): $13-21$

\title{
CONSUMERS' PERCEPTION TOWARDS BANK ADVERTISING AND ITS' IMPACT ON CONSUMER DECISION MAKING
}

\author{
Dr Vijetha Jadda
}

Assistant Professor Department of Business Management

Vikrama Simhapuri University, Nellore Dt 524 320, Andhra Pradesh, India

DOI: http://dx.doi.org/10.38193/IJRCMS.2022.4102

\begin{abstract}
This paper aims to find out the consumers' perception towards bank advertising \& advertisements and its impact on consumer purchase decision. Study is based on exploratory and descriptive research. A structured questionnaire is administered to know the perception of consumers towards bank advertisements. A total of 289 respondents participated in the study. The results show that the respondents consider advertisements as a valuable source of information. The findings suggest that advertisements create a positive impression on the minds of customers and are necessary for the bank to market its services. Consumers 'perception towards bank advertising is fairly positive and agreed to the role \& importance of advertising for consumers' and the economy. The study revealed that advertising is not the only factor which influences a consumer in selecting a bank.
\end{abstract}

KEYWORDS: Advertising, banking, consumer perception, intangibility, Consumer decision

\section{INTRODUCTION}

Advertising performs one of the most important functions in the society that is to inform, it gives people the power of choice, the power of knowledge that helps them make decisions in every day. It is the life blood of any organization. Aaker et al (1992), states that "advertising is more than advertisements alone. It is an institutional part of our society, a social force affecting and affected by our style of life". Hence, advertising by itself became the modern socio-economic system. Liberalization, de licensing, open economies, active stock markets and information technology etc; kindled the faster growth and seamless opportunities in the Indian Advertising Industry. Advertising $\&$ advertisements have become an integral part of today's consumers' lives and society.

Advertising the services is much more complex than advertising the products because of their intangible nature. The intangibility factor has been documented for years as a crucial issue facing services marketers and advertisers (Zeithml, Parasuraman \& Berry, 1985). The salient features like intangibility, inseparability, variability \& perishability are challenging the way that services are 
advertised. Product advertisements \& service advertisements differ mainly in that product advertisements make much more use of the presentation of the offer and competitive advantage, while service advertisements focus more on the means employed, customer benefits and institutional commitments.

In Indian banking industry, it was found that almost all types of media \& advertising is used to promote the banking services. Deciding where to use a banks' advertising dollar can be a painstaking process for ad gurus (Robert Bruce Slater, 1990). The vast majority of the budgets were spent on television and newspaper advertisements, but significant amounts were also targeted for direct mail, mobile banking, magazines, billboards, online advertising and websites too. The advertisers should vest extra efforts while designing advertisements for the banking services.

Understanding consumers' perception towards advertising is crucial for banks because the way it is perceived by consumers determines the advertising effectiveness and customer choice. Advertising plays a vital role in creating affirmative perception \& attitude in the consumers' mind towards the bank's products.

\section{REVIEW OF LITERATURE}

Satendra Thakur \& AP Singh (2011), have found that both the public sector and private sector banks are using almost all types of media to promote their services. According to the consumer perception the most effective tools of advertising are television, followed by newspapers, personal selling, journals \& magazines.

Prasanna Kumar and Venkateswara Raju (2013), tried to assess the influence of advertising through attitudinal buying behavior of consumer and analyze the influence of advertising between male and female. The findings reveal that advertising can change the opinion of the customer about the product. Advertising can easily convince the customer for the product and they should be appealing and engaging the customer to involve in the advertisement.

John Mylonakis (2008), tried to examine the relationship between the bank advertising and the need of bank customers in Greece and its possible influence on potential customers to select their banks. The study has demonstrated the issue of customers' indifference to advertising their decision to cooperate with a bank. Advertising is not the determinant factor in their final choice.

Shani Bashiru \& Alhassan Bunyaminu (2013), studied the influence of advertisements on consumer patronage of the products \& services of selected banks in Ghana. The majority respondents opined that, they conduct business with banks largely as a result of word of mouth recommendation and 
proximity of banks to their communities \& neighbors' than media ads on radio, television \& newspaper. Multiple regression was performed which resulted in minimal correlation between the effect of advertisements and patronage of the products \& services of the banks.

Hutchinson and Rothwell (2002), in their research study tried to understand the public views on the role of advertising and how they 'consume' and 'use' advertising. The findings suggest that public view advertisement as everything that has a name on it. According to them the most effective advertising combines the three factors of everyday culture, entertainment and information. Advertisement that moves into the everyday culture will be sustained and the information and entertainment effects will be further expanded. Hitting all the three factors will maximize the return on advertising investment.

Jebran and Hossain (2012) explored the consumers' perception on general banking activities of a Commercial bank. The key variables identified that affect consumer perception about any bank are consumer loyalty, attention, accessibility, convenience, risks, trust, security, privacy, costs, attitude towards banking and service.

Adholiya et al (2013), tried to examine the factors which influence customer perception positively. The factors of ad like personalization, irritation, credibility, in formativeness and entertainment significantly affects customer perception.

Chun and Wan (2010), explored the perceptions and attitudes towards SMS advertising in Hong Kong. Permission, context, credibility, incentives and entertainment are the five factors studied in the research. The results indicate that credibility and the entertainment are the strongest positive drivers of consumers' acceptance of mobile advertising. Permissions, incentives and context have no use in dealing mobile users to have a favorable attitude towards SMS advertising. The more the acceptance of SMS advertising the more is its influence on the purchasing intentions of the advertised products/services.

\section{METHODOLOGY}

The aim of this research is to find out the consumer perception towards advertising by banks. Objectives of the Study

- To study the consumer perception on advertising in the Indian banking industry.

- To know the impact of consumer perception on consumer decision making.

The below hypothesis was framed to know the impact of demographic variables on the consumer 
perception towards bank advertising.

Ho: There is no significant influence of demographic variables on the consumer perception towards bank advertising.

The major purpose of this research is to know the state of affairs as it exists at present. The research design is exploratory \& descriptive in nature. A structured questionnaire is administered to collect the data from the respondents. A five point likert scale ranging from Strongly Agree (5) to Strongly Disagree (1) was used. The sample size for the study is 350 of which 298 were received in complete form. Sample was chosen through convenience sampling method. The area of survey is restricted to the state of Andhra Pradesh, India. Data analysis was conducted with the help of SPSS software. Descriptive statistics, mean, standard deviation, $t$ test and ANOVA are applied for the collected primary data.

\section{RESULTS \& DISCUSSION}

To examine the demographic profile of the respondents, the present study has considered gender, age, marital status, educational qualifications, employment status, annual income and geographical location. The profile of the respondents was analyzed by tabulating the frequency and percentages based on the primary data collected through survey.

The sample $(\mathrm{N}=298)$ consists of 199 male $(67 \%)$ and 99 female $(33 \%)$ respondents of SBI. Out of 298 respondents, 36(12\%) are in the age group of below 25 years, 96(32\%) respondents are in the age group of 25-34 years, 94(32\%) respondents are in the age group of 35-44 years, 57 (19\%) respondents are in the age group of 45-54 years, and 15(5\%) respondents are above 55 years. Out of 298 respondents $79(27 \%)$ respondents are single and 219(73\%) respondents are married.

The total sample of 298 revealed 20(7\%) respondents from below 10th class, 169(57\%) respondents are graduates, 101(34\%) respondents from post-graduate level and 8(3\%) from other levels of education. Respondents were scattered among seven occupations or employment status. The collected sample consists of $17(6 \%)$ students, $134(45 \%)$ government employees, $82(28 \%)$ private employees, $37(12 \%)$ own business, $16(5 \%)$ housewives and the remaining 11(4\%) belong to other occupations.71(24\%) respondents are earning less than 1 lakh, 165(55\%) respondents are earning 1 to 5 lakhs, 59(20\%) respondents are earning 5 to 10 lakhs and 3(1\%) respondents are earning more than 10 lakh rupees annually. Out of the 298 respondents, 219(73\%) respondents live in urban areas whereas $79(27 \%)$ respondents live in rural areas. 


\section{Consumer Perception on Bank Advertising}

The present section tried to explore the perception of the respondents on the current advertising scenario of the Indian banking industry. Table 1shows the consumer responses recorded for 13 statements designed to measure the perception of the sample respondents towards advertising in banks. From the table it is observed that the highest mean was recorded for the statement that the advertisements are a valuable source of information (Mean $=4.21$ ) and the least mean was recorded for the statement that the advertisements are irritating (Mean=2.53).

The five statements - The advertisements are a valuable source of information (Mean = 4.21), Advertising is good for economy (Mean $=4.15$ ), The advertisements create a positive impression on the minds of customers (Mean = 4.06), The advertisements are necessary for the bank to market its services (Mean =4.08) and the ads enhance the image of the bank (Mean $=4.05$ ) showed that the respondents strongly agreed the role \& importance of advertising both for consumers and the economy. Hence the opinion of the respondents is fairly positive towards marketing of banking services through advertising.

Table 1 Opinions of the Respondents on Bank Advertising $\quad(\mathrm{N}=298)$

\begin{tabular}{|c|c|c|c|c|c|c|c|}
\hline Statements & 1 & 2 & 3 & 4 & 5 & Mean & SD \\
\hline I often read/view ads on banks & 3 & $\begin{array}{l}11 \\
(3.7)\end{array}$ & $\begin{array}{l}14 \\
(4.7)\end{array}$ & $\begin{array}{c}184 \\
(61.7)\end{array}$ & $\begin{array}{l}86 \\
(28.9)\end{array}$ & 4.14 & 0.746 \\
\hline $\begin{array}{l}\text { The ads are a valuable source of } \\
\text { information }\end{array}$ & 2 & 4 & $\begin{array}{l}21 \\
(7.0) \\
\end{array}$ & $\begin{array}{c}174 \\
(58.4)\end{array}$ & $\begin{array}{l}97 \\
(32.6)\end{array}$ & 4.21 & 0.684 \\
\hline Advertising is good for economy & 5 & \begin{tabular}{|l}
8 \\
$(2.7)$
\end{tabular} & $\begin{array}{l}30 \\
(10.1)\end{array}$ & $\begin{array}{c}148 \\
(49.7) \\
\end{array}$ & $\begin{array}{r}107 \\
(35.9) \\
\end{array}$ & 4.15 & 0.835 \\
\hline The advertisements are irritating & $\begin{array}{l}26 \\
(8.7)\end{array}$ & $\begin{array}{c}139 \\
(46.6)\end{array}$ & $\begin{array}{l}85 \\
(28.5)\end{array}$ & $\begin{array}{l}44 \\
(14.8)\end{array}$ & 4 & 2.53 & 0.895 \\
\hline The ads are quite misleading & $\begin{array}{l}31 \\
(10.4)\end{array}$ & $\begin{array}{l}134 \\
(45)\end{array}$ & $\begin{array}{l}64 \\
(21.5)\end{array}$ & $\begin{array}{l}57 \\
(19.1)\end{array}$ & $\begin{array}{l}12 \\
(4.0)\end{array}$ & 2.61 & 1.036 \\
\hline $\begin{array}{l}\text { The ads create a positive impression on the } \\
\text { minds of customers }\end{array}$ & 1 & $\begin{array}{l}6 \\
(2.0)\end{array}$ & $\begin{array}{l}28 \\
(9.4)\end{array}$ & $\begin{array}{c}201 \\
(67.4) \\
\end{array}$ & $\begin{array}{l}62 \\
(20.8)\end{array}$ & 4.06 & 0.640 \\
\hline $\begin{array}{l}\text { Bank ads help increase my standard of } \\
\text { living }\end{array}$ & 5 & $\begin{array}{l}23 \\
(7.7)\end{array}$ & $\begin{array}{l}56 \\
(18.8)\end{array}$ & $\begin{array}{c}150 \\
(50.3)\end{array}$ & $\begin{array}{l}64 \\
(21.5)\end{array}$ & 3.82 & 0.913 \\
\hline $\begin{array}{l}\text { The ads are necessary for the bank to } \\
\text { market its services }\end{array}$ & 3 & \begin{tabular}{|l}
8 \\
$(2.7)$ \\
\end{tabular} & $\begin{array}{l}38 \\
(12.8)\end{array}$ & $\begin{array}{c}163 \\
(54.7) \\
\end{array}$ & $\begin{array}{l}86 \\
(28.9)\end{array}$ & 4.08 & 0.781 \\
\hline
\end{tabular}




\begin{tabular}{|l|l|l|l|l|l|l|l|}
\hline The ads are entertaining \& fun to watch & $\begin{array}{l}18 \\
(6)\end{array}$ & $\begin{array}{l}59 \\
(19.8)\end{array}$ & $\begin{array}{l}91 \\
(30.5)\end{array}$ & $\begin{array}{l}110 \\
(36.9)\end{array}$ & $\begin{array}{l}20 \\
(6.7)\end{array}$ & 3.18 & 1.023 \\
\hline The ads enhance the image of the bank & 1 & $\begin{array}{l}12 \\
(0.3)\end{array}$ & $\begin{array}{l}36 \\
(12.1)\end{array}$ & $\begin{array}{l}171 \\
(57.4)\end{array}$ & $\begin{array}{l}78 \\
(26.2)\end{array}$ & 4.05 & 0.757 \\
\hline I often switch banks because of advertising. & $\begin{array}{l}21 \\
(7)\end{array}$ & $\begin{array}{l}80 \\
(26.8)\end{array}$ & $\begin{array}{l}58 \\
(19.5)\end{array}$ & $\begin{array}{l}116 \\
(38.9)\end{array}$ & $\begin{array}{l}23 \\
(7.7)\end{array}$ & 3.13 & 1.111 \\
\hline $\begin{array}{l}\text { The advertisements are consistent with the } \\
\text { bank's image }\end{array}$ & 5 & $\begin{array}{l}16 \\
(5.4)\end{array}$ & $\begin{array}{l}48 \\
(16.1)\end{array}$ & $\begin{array}{c}184 \\
(61.7)\end{array}$ & $\begin{array}{l}45 \\
(15.1)\end{array}$ & 3.83 & 0.807 \\
\hline Advertising helped me in selecting SBI & $\begin{array}{l}11 \\
(3.7)\end{array}$ & $\begin{array}{l}43 \\
(14.4)\end{array}$ & $\begin{array}{l}50 \\
(16.8)\end{array}$ & $\begin{array}{c}147 \\
(49.3)\end{array}$ & $\begin{array}{l}47 \\
(15.8)\end{array}$ & 3.59 & 1.035 \\
\hline \multicolumn{7}{|c|}{ Overall “Perception" Factor Score } \\
\hline
\end{tabular}

Note: The values specified in the brackets represent percentages.

Anchors: 1- Strongly Disagree, 2- Disagree, 3- Neither agree not disagree, 4- Agree and 5- Strongly Agree.

The two statements that the advertisements are irritating (Mean=2.53) and the advertisements are quite misleading (Mean $=2.61$ ) showed the least mean scores among the thirteen statements framed. The means report that the respondents do not consider advertising by banks as irritating and misleading which is also a positive facet of bank advertising.

The respondents gave a rather lesser mean score for the advertisements are entertaining \& fun to watch' (Mean= 3.18) which says that the bank advertisements are often low in the entertainment dimension.

Advertising helped me in selecting SBI (Mean = 3.59) and I often switch banks because of advertising $($ Mean $=3.13)$ revealed that advertising is not the only factor which influences a consumer in selecting or switching a bank.

Table 2 shows the influence of demographic variables on the consumer perception of SBI respondents with respect to bank advertising.

Ho: There is no significant influence of demographic variables on the consumer perception towards bank advertising. 
Table 2 Test of Significant Influence of Demographic Variables on Consumer Perception towards Bank Advertising

\begin{tabular}{|c|c|c|c|c|c|c|}
\hline $\begin{array}{c}\text { Demographic } \\
\text { Variables }\end{array}$ & Characteristics & $\mathbf{N}$ & Mean & SD & $\begin{array}{l}\text { t value/ } \\
\text { F value }\end{array}$ & $\begin{array}{c}\text { p- } \\
\text { value }\end{array}$ \\
\hline \multirow[b]{2}{*}{ Gender } & Male & 199 & 70.3 & 9.2 & \multirow[b]{2}{*}{0.536} & \multirow[b]{2}{*}{0.592} \\
\hline & Female & 99 & 69.73 & 7.283 & & \\
\hline \multirow{5}{*}{ Age } & Below 25 YRS & 36 & 67.23 & 8.179 & \multirow{5}{*}{2.043} & \multirow{5}{*}{0.088} \\
\hline & $25-34$ & 96 & 69.73 & 8.112 & & \\
\hline & $35-44$ & 94 & 70.99 & 8.511 & & \\
\hline & $45-54$ & 57 & 70.12 & 9.287 & & \\
\hline & $55 \&$ Above & 15 & 73.85 & 9.346 & & \\
\hline \multirow[b]{2}{*}{ Marital Status } & Single & 79 & 68.77 & 9.037 & \multirow[b]{2}{*}{1.617} & \multirow[b]{2}{*}{0.107} \\
\hline & Married & 219 & 70.59 & 8.409 & & \\
\hline \multirow{4}{*}{$\begin{array}{c}\text { Educational } \\
\text { qualifications }\end{array}$} & Below $10^{\text {th }}$ & 20 & 72.5 & 8.117 & \multirow{4}{*}{2.852} & \multirow{4}{*}{0.038} \\
\hline & Graduate & 169 & 70.97 & 8.77 & & \\
\hline & Post Graduate & 101 & 68.5 & 8.202 & & \\
\hline & Others & 8 & 66.21 & 8.052 & & \\
\hline \multirow{7}{*}{ Employment status } & Student & 17 & 65.35 & 9.248 & \multirow{7}{*}{1.623} & \multirow{7}{*}{0.141} \\
\hline & Govt. Service & 134 & 70.98 & 8.255 & & \\
\hline & Private Sector & 82 & 70.58 & 8.008 & & \\
\hline & Own Business & 37 & 69.43 & 11.644 & & \\
\hline & Pensioner & 1 & 59.38 & & & \\
\hline & House Wife & 16 & 67.97 & 5.619 & & \\
\hline & Others & 11 & 69.74 & 5.334 & & \\
\hline Annual Income & Less than 1.00 lakh & 71 & 67.54 & 7.818 & 4.742 & 0.003 \\
\hline
\end{tabular}

\section{Source: Computed data}

T-test was conducted to now the influence of gender marital status and geographical location of the respondents towards consumer perception on bank advertising. It is observed that geographical location is the only demographic variable which is having a significant influence on consumer perception $(\mathrm{t}$ value $=1.980, \mathrm{p}$ value $=0.049)$. The urban $($ Mean $=70.70)$ showed better perception compared to rural $($ Mean $=68.47)$. 
Since $\mathrm{p}$ value is greater than 0.05 there is no significant influence of gender and marital status on the consumer perception towards bank advertising.

ANOVA was applied to now the significant influence of age, educational qualifications, employment status and annual income on the consumer perception with respect to bank advertising. It is observed from the analysis that there is a significant influence of educational qualifications ( $\mathrm{F}$ value $=2.852, \mathrm{p}$ value $=0.038)$ and annual income $(F$ value $=4.742, \mathrm{p}$ value $=0.003)$ on the consumer perception.

The respondents who are below 10th class level of education (Mean $=72.50$ ) scored better perception compared to other educational backgrounds. Whereas the respondents in the annual income level of $5,00,001$ to $10,00,000$ lakhs (Mean $=72.43$ ) showed higher perception on bank advertising than the other income levels. It is noted from the table that there is no influence of age and employment status on the consumer perception towards bank advertising as the mean scores do not differ significantly and the $\mathrm{p}$ value is greater than 0.05 .

\section{The hypothesis is rejected.}

Hence, there is a significant influence of demographic variables on the consumer perception towards bank advertising.

\section{CONCLUSION}

The present study revealed that the consumers are aware and agreed upon the role \& importance of advertising both for consumers \& economy. Consumers reacted fairly positive towards marketing banking services through advertising. Bank advertisements are not considered as irritating and misleading which is also a positive facet of bank advertising. Consumers think that bank advertisements are rather bland, and often score low in the entertainment dimension. Geographical location, education \& annual income have a significant impact on the consumer perception towards bank advertising. The study found that advertising is not the only factor which influences a consumer in selecting a bank or switching a bank. Advertising is not the main criterion for consumers' in choosing a bank. However, it is a prerequisite, as it verifies a bank's critical presence in the market and plays a significant role in consumer decision making.

\section{REFERENCES}

1. Slater, Robert Bruce. (1990). Bankers Binge on Bank Ads. Marketing Watch. June, p. 63.

2. Thakur, Satendra. \& Singh, A.P. (2011). Search and Research. Promotional Strategies: A Study in Banking Industry Vol 2(3). P.17-20. 
3. Dr. Kumar, D. Prasanna \& Raju K. Venkateswara. (2013). The Role of Advertising in Consumer Decision Making. IOSR journal of Business and Management Vol 14(4). P.37- 45.

4. Singh, J.D. (1982). Bank Advertising in India: 1971 - 1980. Prajnan. P.255-272.

5. Mylonakis, John. (2008). The influence of banking advertising on bank customers: an examination of Greek bank customers' choices. Banks and Bank Systems Vol 3(4). P.44- 48.

6. Bashiru, Shani \& Bunyaminu, Alhassan. (2013). A Critical Analysis on Advertising Bank Products and Services in Ghana. International Journal of Marketing Studies Vol 5(3). P.117-132.

7. Ford- Hutchinson, Sally. Rothwell, Annie. (2002). The Public's perception of advertising in today's society. A report on the findings from a research study prepared for the Advertising Standards Authority, London.

8. Jebran, Jafirullah Khan. \& Hossain Md. Afzal. (2012). Consumer's Perception on General Banking Activities of Commercial Banks: A Study in the Banking Context of Bangladesh. European Journal of Business and Management Vol 4(7). p. 54-70.

9. Adholiya, Ashish. Dave, Pankaj. \& Adholiya, Shilpa. (2013). An Empirical Study of Various Advertisement Factors Influencing Customer's Perception for Telecom Companies: In Reference to prepaid and Post-paid Subscribers of Udaipur, Rajasthan. International Journal of Applied Services Marketing Perspectives Vol 2(1). P.245-249.

10. Liligeto, Rejiieli. Singh, Gurmeet \& Naz, Rafia. (2014). Factors Influencing Consumer Perception towards TV and Newspaper Advertising. The Journal of Pacific Studies Vol 34(2). p.6485.

11. Rani, Malika. (2012). A Study on the Customer Perception towards E-Banking in Ferozepur District. International Journal of Multidisciplinary Research Vol 2(1). P.108- 118.

12. Chun, Gavin Cheung Sze \& Wan, Li Lilly Kar. The Perceptions and Attitudes towards SMS Advertising in Hong Kong. [Online] Available from: http://libproject.hkbu.edu.hk/trsimage/hp/07013930.pdf. 